\title{
Study on the Chinese Grass-roots Government on Administrative and Personnel Management
}

\author{
Yanxia Huang \\ Jincheng College of Sichuan University \\ Chengdu, Sichuan, China \\ 18008083462@163.com
}

\begin{abstract}
On the basis of human resources management theory, the grass-roots government human resources management mode in China was outdated. For the management functions of human resource in allocation optimizations are not into full play. What's worse, it is not adapted to the pace of development of the times and failed to form a new government human resources management mode in a new era. In addition, as grass-roots of functions sector and government image, township government's executive force is vital. It is of new and original idea in this paper for township government human resources management to introduce enterprises' new concept and mode to promote China public sector in human resources management system. This study aims to understand the grassroots government personnel and human resource management research including enhance the government of implementation force and efficiency of public sector human resources which can give full play to the government's service function.
\end{abstract}

Keywords-administration management, human resources management, personnel administration, local government, constructive suggestions

\section{CHARACTERISTIC OF THE GOVERNMENT'S HRM}

Government's human resources management has its uniqueness because of the characteristics of the Government itself and the characteristics of HR department. This is mainly for:

Firstly, the personnel administration is complex. The government departments are under horizontal differentiation and vertical levels control.

Secondly, it has specific legal regulation which ensures that Government departments can exercise legitimate authority.

Thirdly, it has more non-quantitative characteristics, such as the assessment of civil servants ' political demands, morality and talent. Human resource management in government departments need to develop performance indicators which are applicable to governmental organizations.

\section{SEPARATE GOVERNMENT AND ENTERPRISE HRM.}

\section{A. Great political demands}

Political demands are so great that government have to pay more attention to political culture than companies. Although purpose of the enterprise is profit, enterprises should also be more focused on employees' knowledge, professional skills, work experience, economic benefits as well as other factors during recruiting.

\section{B. Diversity in responsibilities}

It assumes diverse responsibilities in this position. Targets are always a little bit more abstract than business goals. Work is hard to quantify as well. Government performance management is regarded as complex in modern society.

\section{Differences in oversight mechanisms}

Government department is a public service institution, which means all the activities must be provided to serve the public. Besides, it should be monitored and evaluated by the criterion of the public and subject to public supervision.

Influenced by global government human resources management change, our government human resources management system has been reformed continuously after Opening up reform [1]. And which requires the government department of human resources managers explore a suitable management concept and behavior, like entrepreneurs, to be enterprising and innovative.

Whether in decentralization, performance pay, deregulation or privatization, scholars have maintained a basic consensus about the responsibility of the public administration is constantly adapted to the changing environment [2]. In the reform of the civil service, most countries in the world enhance the core functions of human resources management, ease the traditional value rules, decentralize personnel functions and enhance institutional autonomy to improve the administrative efficiency of the government.

\section{THE CURRENT GOVERNMENT'S HR WEAKNESS}

\section{A. Lack flow mechanism and service consciousness}

Some workers believe that the work in government department is very stable. Reporting for duty on time every day without too much work to do and getting a good salary and welfare every month seem to be the whole. However, poor enthusiasm, seldom initiative and lower consciousness of service of workers makes it difficult to level the playing field in such a management mode. In that condition, the workers may be treated unequally and result in a depressing atmosphere and flowing mechanism. The overall work quality of the unit is not appropriate. 


\section{B. Deficiencies in incentive system and evaluation mechanism}

The appraisal performance, the salary of the welfare and the promotion of the position constitute the incentive mechanism of the grass-roots institutions in our country. Chinese civil service examination system is a blurred existence which can easily to become a mere formality, neglecting the usual job evaluation. Annual examination cannot fully cover the work reality of a year. Under the guidance of egalitarianism, the evaluation takes simple turns. Many managers are reluctant to be strict. Their leading to the assessment of things is ambiguous.

Traditional performance evaluations are often taken for granted as "confidential". The invisibility of the personnel appraisal has aggravated the uneasiness of the appraisal and the distrust of the personnel department. It also interferes with the role of education in the evaluation of staff. And the distrust of the personnel department will also hinder the evaluation of education effect on staff [3].

The salary of contract officers and staff has a big gap which is the main problem in human resources management. Unreasonable salary restricts the contract staff to carry out the efficient work to a great extent. Such treatment made some psychological complaints exist in contract workers. As a result, the quality of work is more and more mediocre and the worker is hard to be promoted.

Their salary is in the position-salary mode which relatively stable, while the performance matching degree is relatively poor. So they cannot achieve the work achievement and salary correlation. The performance appraisal in the grass-roots government is always a simple form. It can't reflect the work quality, the ability and even the work attitude of the staff.

\section{Lacking modern HRM machanism}

The institution is different from ordinary enterprises in the process of human resources management because of the unique political attributes and work tasks. It is difficult to form a specialized human resources management department system which is able to deal well with its own system professionally just result from the limitation of organization structure in government.

The importance of human resource planning in the grassroots government of our country needs to be strengthened. We need professional human resource planning agencies and professionals to fully realize the role of this management. Human resource management always has to adhere to the daily work of the grass-roots units, so that the role of this management cannot be fully realized.

In addition, the backward concept of human resources management is also a cause of poor management quality. In order to promote the development of grass-roots units better, the grass-roots level of human resources managers need to constantly absorbing new knowledge and idea, learning new skills, enriching their own contents, enhancing the level of human resource management.

\section{Mixed job and unclear responsibility}

The Administrative officers wear several hats in grass-roots units is a very common phenomenon. Reducing the staff and save manpower costs, but also contributing to the employee's job responsibilities are not clear. Workers do not clear the boundaries of their tasks and responsibilities. Once there was a problem, there will be a pile of excuses to evade.

Similarly, the staffs do not understand the work scope and quality of work standards. It's difficult for them to guarantee the quality of work. And work attitude are generally perfunctory, lacking of sense of responsibility. It's easy to serve the people inefficiently and obstruct the interests of the people.

\section{E. Insufficient training of basic human resources}

Units did not pay full attention to personnel training. The professional skills of staff do not meet community development needs, leading to the actual problems of low productivity. If the staff's professional skills are not high in some technical departments, they can't maximize their service capacity and affect the overall function of social services building.

The traditional personnel management is training at all levels of party school and administration apartment [4]. Furthermore is the most of the grass-roots training work only attaching importance to the education about ideological. But with the economic development, knowledge and skills requirements of the civil service are increasing, which gradually revealed defects of primary human resources training and development, mainly in three aspects. First, awareness is not in place. Followed by content and methods are lack of effectiveness which cannot meet the different demands of different objects. Last is the lack of appropriate training plans and training teachers.

\section{F. Lacking scientific allocation of human resources}

In recent years, a large number of outstanding cadres, veterans and college graduates have emerged from various local governments, gradually becoming the backbone of grassroots government work. Although the number of human resources in grass-roots government has improved a lot, there are still problems. The organizational structure is jumbled, and the proportion of the deputy director level is too large. The age structure is unreasonable, the serious lack of the civil servant under 30 years old. Finally, the cultural structure is unreasonable and the proportion of students with professional knowledge is small.

\section{G. Dependent supervision mechanism}

Grass-roots government supervision mechanism is an important component in human resources management, which is closely related to the immediate interests of the people. However, there is a lack of external supervision and restriction mechanism of government power [5].The inappropriate behavior of local governments cannot be stopped in time, such as prevention and correction in a timely manner after the incident. What's worse, the internal commission for discipline inspection and supervision are often opaque and rigid. 
Dependent supervision mechanism impacts the supervision process of the rule of law seriously.

\section{CONSTRUCTIVE RECOMMENDATIONS}

These above problems restricted the further development of the grass-roots government. In order to promote the development of grass-roots government, a number of targeted solutions are recommended: establish the concept of modern human resources management; optimize the allocation of human resources; improve the mechanism for human resources training; establish and unimpeded human resources flow mechanism; establish and perfect the evaluation and incentive mechanism of human resources; strengthen human resources supervision mechanism.

\section{A. Deepen the human-oriented concept}

Basic government's primary goals are to ensure that local government units running efficiently provide high quality public services and manage grass-roots workers scientifically. In order to form a good atmosphere of human resources management in public institutions, we need to disseminate relevant ideas, learn to ordinary workers and take hold the people-oriented management concept [6]. Making the "taskoriented" traditional personnel management style transformed into the "people-oriented" of human resources management in the public sector.

Reasonably satisfying the legitimate human needs is the essence of human-centered management requirements, which not only refers to the organization respect staff, meet their survival, safety, society respect and self-actualization needs, but also to give spiritual comfort, emotional care and keeping the feelings from the organization level.

A number of targeted solutions are recommended: establish various supporting management mechanisms and hold the long-term management at institutions to establish a complete and efficient system. It is of importance to encourage employee to innovate and avoid stifling work atmosphere. Only workers remain active, the development of grass-roots institutions do promote constantly.

\section{B. Optimize the HRM system and clarify position function}

According to the changes in the administrative environment, government should be based on its strategic goals and core values to check working procedures, simplify redundant structure and content of management, clear responsibilities of every job to build a lean organization and make the government's role into full play.

1) The essence of human resource management in government departments is to select talents, cultivate talents and use talents for government development. The optimal allocation of human resources of grass-roots government departments is making the executive system adapt for the changes of administrative environment, adjusting the structure, function and management pattern of itself to reduce administrative costs and promoting the dynamic balance between administrative environment and resource. It is above all to achieve the administrative efficiency maximization.

2) The first and most is realizing the reformatory system of selection of the competition. Human resource management of grass-roots government departments should realize the rationalization of professional structure, age structure. What is more, the human resource management of the grass-roots government departments should realize the rationalization of the vertical allocation of government functions and powers.

\section{Pay linked strengthening to performance}

Local Government should establish reasonable system about remuneration and performance appraisal. Staff salaries need to be based on performance appraisal. The more work, the more wages, which in distribution according to work. The core to improve government efficiency is implementing performance management and enhancing competition. Setting up a scientific and effective performance evaluation system to make comprehensive, objective, fair and accurate assessment of executive performance and moral performance is very useful. What we should do is just that according to this payroll patterns to enhance the fairness of wages, carry out specific services actively and raise the overall efficiency of the unit.

1) It is essential to establish scientific target responsibility system, making the goals become the basis and standard of each work. What is more, it is do good for them by establishing scientific evaluation index, evaluating the competence and development potential of the cadre through performance evaluation. Especially, changing the current situation about administration qualitative than quantitative evaluation in the personnel management system and exploring the integration of qualitative and quantitative indicators together are another way to deal with it.

2) According to virtue, ability, diligence, performance, quality and other aspects of the assessment requirements, full account of different types of status, task differences, working conditions to develop a completely scientific and quantitative criteria system and evaluate cadres.

3) On the other side, there are some auxiliary means, such as advancing the means of technology applications in administration personnel evaluation process, introducing the modern information technology, giving full play to network, computers and other modern ways to evaluate executive cadre and personnel .

\section{The emphasis on professional ability training}

Workers should have high professional competence. Aimed at the current situation of some staffs' low professional skills, departments should pay attention to cultivate staff's professional ability and carry out a variety of training activities. Specifically, local government ought to follow the lectures of different professional services, promote working awareness and enhance the idea of service better for society.

1) In the light of staff's working conditions, government should reward for going out to study and improve the overall quality of the outstanding people. For skilled work, it 
necessary to introduce new working machinery and raise the overall advancement of the work.

2) For gradually perfect training mechanism and highlight grass-roots human resource training target, there are a number of targeted solutions are recommended: aim at demandorientation and sustainable development, establish grass-roots training of human resources, create the learning-type government, strengthen the pertinence and effectiveness of human resources training.

3) What is more, setting up training projects about selfreporting system is a brilliant way. Government should combine training program management with self-selected mechanism and play the guiding role of the organization. According to the professional characteristics of the unit's overall training plan, it is of significance to combine organizational development with job needs to set the appropriate training courses and staff self-reporting training program. Take the relative classification training on the basis of their business needs.

\section{E. Strengthening government supervision mechanism in HRM}

Local government human resources management should establish a complete system of supervision system of grassroots government to strengthen oversight mechanisms.

1) Improve the power organs of legal supervision. The basic people's congresses in China are the power of grass-roots institutions in our country with the powers and obligations about supervising local government.

2) Advocacy NGOs supervise the implementation and development in local government human resources management. Encourage citizen to act for their own interests and the power of grass-roots government human resources management through the legal norms and culture propaganda.

3) Build a broad, flexible social supervision network. Enhance community awareness of public participation in local government oversight. Motivate social public enthusiasm about supervision is another important guarantee to improve the monitoring effectiveness of the civil service. Above all methods' goals is just to Strengthen government supervision mechanism in human resources management.

\section{CONCLUSION}

From the perspective of human resources management modernization, it provides organizational guarantee for harmonious society by optimizing the structure of human resources, building grass-roots government human resources training system, setting up new areas of human resources management in public management and forming a fair and efficient grass-roots government human resources management system. The grass-roots government departments are the ultimate implementation carriers of the majority policies of the state. Since they work face to face with citizens, the efficiency and capacity of their work represents the whole government. Human resource is the inner motive power of local governments. And it is very necessary to optimize the basiclevel government human resource management system for basic-level government work. So their problems should be worthy of attention and research. When one day people no longer worship civil servants, it will be proved seemingly that the Chinese government's personnel work has gained some practical achievements. This paper supports that winning the trust and respect from public and serving the public better in the government administrative management need to through the rational allocation of human resources, matching personnel and post and improving the efficiency of execution.

\section{REFERENCES}

[1] Louise Thornthwaite, The origins of personnel management: reasserting the public sector experience, Journal of Management History, 2012, Vol.18 (3), pp.312-330

[2] Todd Jordan, R. Paul Battaglio, Jr, Are We There Yet? The State of Public Human Resource Management Research, Public Personnel Management, Vol 43, Issue 1, pp. 25 - 57,First published date: December-26-2013

[3] Gene A. Brewer, J. Edward Kellough, Administrative Values and Public Personnel Management [J].Public Personnel Management, 2016, Vol.45 (2), pp.171-189

[4] Xu Min. Local government human resources management problem and countermeasure of China [J].Human resource management, 2012, (07): 96-98. (In Chinese)

[5] Lin Ying. Analysis on the transformation of the personnel management in the public sector in China.[J].Human resource management, 2014, (01): 15-6(In Chinese)

[6] Lu Shan. Study on problem and countermeasure of human resource management of our local government.[J].Journal of Jinzhong College.2017, (04): 34-2. (In Chinese) 